\title{
Effects of Rectal Midazolam Sedation on Cystometric Parameters in Children
}

\section{Rektal Midazolam Sedasyonunun Çocuklarda Sistometrik Parametrelere Etkisi}

\author{
Sengül ÖZMERT'1 , Feyza SEVER', Hüseyin Tuğrul TiRYAKi²
}

\author{
'University of Health Sciences, Ankara Child Health and Diseases Hematology Oncology SUAM, Department of Anesthesia and \\ Reanimation, Ankara, Turkey \\ 2University of Health Sciences, Ankara Child Health and Diseases Hematology Oncology SUAM, Department of Urology, \\ Ankara, Turkey
}

\begin{abstract}
Objective: We aimed to investigate the effects of rectal midazolam sedation on the cystometry urodynamic procedure in this study by retrospectively comparing the cases that had received and not received sedation before the cystometry procedure.
\end{abstract}

Material and Methods: Twenty children who underwent cystometric evaluation with and without midazolam administration were retrospectively investigated from the hospital records between 01 January 2014 and 31 December 2016. We compared cystometry measurement values of patients with and without sedation.

Results: 20 cases ( 15 female, 5 male) were evaluated in our study. The mean age was $8.65 \pm 2.56$ years. Comparison of the cystometry results with or without sedation in this patient group revealed no significant difference between the parameters $(p>0.01)$. The parents of the patients were asked about their satisfaction and a statistically significant difference was found between the groups ( $p>0.01)$.

Conclusion: We believe that sedation with rectal midazolam is a safe, effective and convenient option during cystometry, especially in the young age group. We did not find midazolam to cause any effect on cystometry data in this study.

Key Words: Child, Cystometry, Midazolam, Rectal

öz

Amaç: Çalışmamızda retrospektif olarak sistometri uygulamasından önce sedasyon verilen ve verilmeyen olgular karşlaştırlarak rektal midazolam sedasyon uygulamasının ürodinamik sistometri uygulaması üzerine etkilerinin incelenmesi amaçlandı.

Gereç ve Yöntemler: Hastane kayıtlarından 01 Ocak 2014 ile 31 Aralık 2016 tarihleri arasında midazolam uygulaması yapılan ve yapılmadan sistometri gerçekleştirlen 20 olgu geriye doğru değerlendirilerek incelemeye alındı. Bu hastalarda sedasyonlu ve sedasyonsuz sistometri ölçümleri karşılaştırldd.

Bulgular: Çalışmamızda 20 olgu (15 kı, 5 erkek) değerlendirmeye alındı. Ortalama yaş $8.65 \pm 2.56$ yaşdı. Bu hastalarda sedasyon yapılarak ve yapılmadan gerçekleștirilen sistometri sonuçları karşılaştııldığında tüm parametrelerde anlamlı bir fark bulunmadı ( $p>0.01)$. Hasta ebeveynlerinin sedasyon uygulamasından memnuniyeti sorgulandığında gruplar arasında istatistiksel olarak anlamlı fark olduğu görüldü ( $p>0.01)$.

Sonuç: Sistometri esnasında özellikle küçük yaş grubunda rektal midazolam uygulamasının güvenli, etkili ve uygun bir seçenek olduğuna inanmaktayız. Çalısmamızda midazolamın sistometri verilerin üzerinde herhangi bir etkisi bulunmamıştır.

Anahtar Sözcükler: Çocuk, Sistometri, Midazolam, Rektal

\section{INTRODUCTION}

Cystometry is an invasive investigation method used for the diagnosis and follow-up of urination disorders in children.
Anxiety at a high rate of $61-71 \%$ is known to develop during cystometry, originating from the unpleasant experiences of bladder and rectal catheterization (1,2). Additionally, the request made by a stranger to fill the bladder and urinate in an unfamiliar 
environment increases the stress of the child and parents (3). These factors make cystometry difficult and can affect the result. The child should be able to stay calm and cooperate and the drug used for sedation should not affect the cystometry values so that an accurate and reproducible procedure can be ensured (4). A variety of pharmacological interventions have been found effective for the cystometry which was in agreement with higher parental satisfaction scores.

Midazolam is a benzodiazepine with sedative, anxiolytic and amnestic effects. It is a valuable drug as it enables the patient to stay awake and cooperate for cystometry, has a rapid onset of action and short duration of effect without any serious side effects, causes partial anterograde amnesia, can be administered easily, and can be administered effectively through the intramuscular, intravenous, intranasal, rectal, oral or sublingual routes $(2,3,5-7)$. Its nasal or oral use can be difficult in children due to the nasal irritation it causes and the unpleasant taste leading to spitting the drug out. The full dose of the drug can be made available with rectal administration. The ability to reverse midazolam's effect with flumazenil is a distinct advantage regarding safe use.

No studies have evaluated the effect of rectal midazolam on children undergoing cystometry with sedation, the parents and the procedure itself. We aimed to investigate the effects of sedation on the cystometry urodynamic procedure in this study by retrospectively comparing the cases that had received and not received sedation before the cystometry procedure at our clinic. The parents were also asked to compare the cystometry experience with and without sedation.

\section{MATERIAL and METHODS}

A total of 20 ASA I-II pediatric cases who underwent cystometry with and without sedation at the Pediatric Urology Clinic between 01 January 2014 and 31 December 2016 were retrospectively investigated from the hospital records. Ethics committee approval for the study was obtained from Ankara Children's Health and Diseases, Hematology Oncology Training and Research Hospital ( 2017-022). This study included the cases that underwent firstly cystometry evaluation without sedation, and then cystometry evaluation with rectal midazolam sedation a mean duration of 11 months later in order to decrease the procedure anxiety. Patients underwent direct urodynamic investigation without sedation with the routine route. Twenty patients who required redo cystometry evaluation because of failure of the treatment with midazolam sedation as noted in our hospital records were evaluated to compare the rectal midazolam effect on cystometry. Patients who underwent cystometry due to urinary incontinence, dysfunctional elimination syndrome, vesicoureteral reflux, past posterior urethral valve surgery, and recurrent urinary tract infection were included in the study. Cases that were ASA III or ASA IV, and patients with an active urinary system infection, severe cardiac and respiratory dysfunction, airway abnormalities, known psychiatric disease, anxiolytic or sedative drug use, and a disease affecting urinary tract sensation (neurogenic bladder) were excluded from the study.

The cases that were to be sedated were fasted for a minimum of 6 hours before the procedure using the routine protocol of our Anesthesia Clinic. Rectal midazolam administration at a dose of $0.3 \mathrm{mg} / \mathrm{kg}$ (maximum $15 \mathrm{mg}$ ) was chosen by the anesthetist. The calculated dose was given rectally. All patients had their parents with them during the procedure and the experienced urodynamics nurse administered a lubricating gel during urethral and rectal catheterization.

All patients investigated with rectal midazolam sedation were routinely monitorized at our clinic and the heart rate, blood pressure, oxygen saturation, the Wisconsin Hospital of Children Sedation Scale (CHWSS) score and the Groningen Distress Rating Scale (GDRS) score (1=Calm; 2=Moderate distress; $3=$ Severe stress, under control; 4=Severe stress, out of control; $5=$ Panic) were recorded at room entry, the 10th and 20th minutes after drug administration, and at the catheterization, bladder filling, urination and room exit stages $(2,4)$. Urethral and rectal catheter insertion during the cystometry procedure was allowed when the CHWSS score was 5 or less. Intravenous midazolam at a dose of $0.05 \mathrm{mg} / \mathrm{kg}$ was administered via a vascular access for sedation to patients with a GDRS value of 4 and above. The patients were sent home after being monitored at the recovery unit following the procedure. Cases with a GDRS score of 4 and higher who wanted sedation did not undergo cystometry as the results would not be healthy.

Standardized uroflowmetry and cystometry with EMG were performed to evaluate detrusor and sphincter functions during bladder filling and emptying (8). The bladder was catheterized with a $6 \mathrm{~F}$ catheter and the bladder was emptied. An $8 \mathrm{~F}$ Catheter was placed in the rectum to monitor the intraabdominal pressure. Three electrodes were attached to the perineum to record EMGs. The bladder was filled with normal saline solution at room temperature at a rate of $<10 \%$ of bladder capacity per minute. Bladder capacity was calculated for age based on formula $E B C=($ age in years +2$) \times 30 \mathrm{ml}(9)$. The bladder was filled until urgency or maximum fullness/discomfort was reported. At the end of filling, the filling catheter was removed and the patient asked to void into a flowmeter. Detrusor overactivity (DO) was diagnosed as contractions greater than $15 \mathrm{~cm} \mathrm{H} 2 \mathrm{O}$ during filling. Small bladder capacity was defined as bladder volume in the absence of DO less than $85 \%$ of EBC for age based on the formula. Detrusor sphincter dysynergia was defined as increased sphincter EMG activity during a detrusor contraction without straining. After measuring the micturition variables, the residual urine volume was measured and procedure completed. The maximum cystometric capacity, contractility, compliance and intravesical pressures were recorded. The maximum flow rate and EMG characteristics were recorded during micturition. 
Patients who underwent cystometry investigation with and without rectal midazolam sedation were respectively evaluated. The anesthesia forms, cystometry measurement values and diagnoses of the cases included in the evaluation were recorded from the hospital records. The duration from the administration of the drug until the procedure and the duration from the beginning of the procedure to the end were calculated from the urodynamic laboratory records. The families of the patients were called by phone and asked whether they were satisfied by the sedation during the cystometry procedure. The parents were also asked to compare the procedure with previous experiences.

\section{Statistical Analysis}

Statistical analysis was performed by using the IBM SPSS Statistics for Windows 22 (Armonk, NY: IBM Corp) software.

Table I: Urodynamic diagnoses in 20 patients.

\begin{tabular}{l|c}
\hline Urodynamic Diagnosis & $\mathbf{n = 2 0}$ \\
\hline Normal urodynamic findings & $6(30 \%)$ \\
Overactive bladder & $5(25 \%)$ \\
Low capacity bladder & $7(35 \%)$ \\
Dysfunctional urination & $2(10 \%)$ \\
\hline
\end{tabular}

Frequency, percentage for categorical data and mean \pm standard deviation or median (min-max) for numerical data were calculated as descriptive statistics. The Wilcoxon test was used to compare the values before and after sedation. A P value of less than 0.05 was considered statistically significant.

\section{RESULTS}

A total of 20 patients consisting of 15 females and 5 males aged 5-14 years were included in the study. The mean age was $8.65 \pm 2.56$ years. Twenty patients who received sedation had undergone a cystometry procedure without sedation 4-18 months (mean 11 months) ago. In this group, there was no response to treatment so the cystometry investigations were repeated because of persisting symptoms.

Sixteen patients included in the study had undergone cystometry due to urinary incontinence, and one each for dysfunctional elimination syndrome, vesicoureteral reflux, past posterior urethral valve surgery, and recurrent urinary tract infection. Urodynamic diagnoses of the patients are shown in Table I. The cystometry values of these patients before and after sedation are compared in Table II.

Table II: The cystometry values of 20 patients with and without sedation.

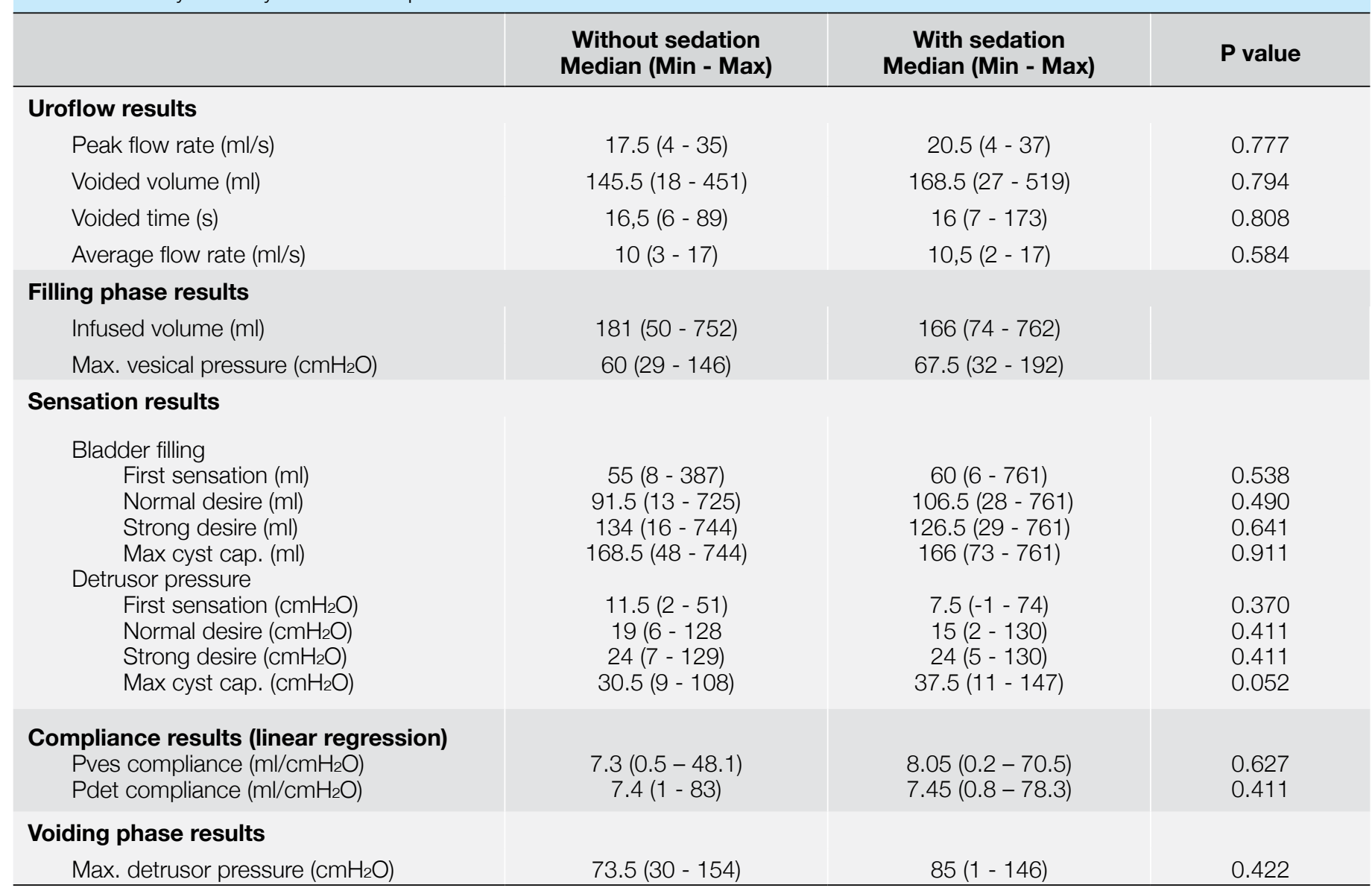


The parents of the same patients were asked to compare the two procedures regarding sedation. Seventeen of the 20 parents expressed that the procedure under sedation was better while two stated no difference between the two and 1 stated that the procedure without sedation was better.

\section{DISCUSSION}

Cystometry study is the basic diagnostic method in children with a lower urinary tract symptom and the procedure may need to be repeated to monitor the effectiveness of the treatment. The bladder and rectal catheterization performed during this procedure cause fear and anxiety in pediatric patients. Children may show extreme anxiety during this procedure, especially if they have previous painful experiences. It is therefore sometimes not possible to perform a cystometric urodynamic study in these patients. Methods such as having the parents present, the use of lidocaine gel during catheterization, distraction techniques, warm infusion fluids and hypnosis have been recommended because they decrease the pain and anxiety that occur due to the catheterization during the procedure (7,10-13). However, some children continue to show serious stress despite these methods and sedation becomes inevitable in such cases. Various anesthetic agents such as propofol, ketamine, midazolam, opioids, and inhalation anesthetics have been used for this purpose. However, some of these drugs are known to affect cystometry results (14-19).

Sedation is not administered routinely for cystometry at the urodynamics outpatients of our hospital. Experienced urodynamics nurses detect patients who are anxious and have difficulty complying and therefore need sedation. Thus we can decrease the failed procedures with early detection of patients who require sedation.

The agent used for sedation in children should enable performing the procedure by decreasing stress and should also not affect the measurements. Benzodiazepines provide sedation, anxiolysis and amnesia but do not have an analgesic effect. Midazolam is a benzodiazepine with a rapid effect of short duration and enables quick recovery. It provides great flexibility in terms of drug administration options, especially in pediatric cases, since it can be administered via various routes such as oral, intranasal, sublingual, rectal, intramuscular and intravenous (7). Its nasal or oral use can be difficult in children due to the nasal irritation it causes and the unpleasant taste leading to spitting the drug out. Although the full dose of the drug can be made available with rectal administration, there may be fear and shame when this route is used. We prefer the rectal use of midazolam because of no irritation, no spitting, fast action and the need for only a low amount of drug compared to the oral or nasal route.

Twenty patients who received sedation in this study had undergone cystometry without sedation about a year ago. A single dose of rectal midazolam did not affect the cystometric urodynamic results and provided adequate comfort for the procedure in our study. In the group without sedation, five patients could not urinate after cystometry. On the contrary, patients with rectal midazolam sedation urinated properly after cystometry. Comparison of the cystometry results with or without sedation in this patient group revealed no significant difference. The lack of a difference between the results indicates that rectal midazolam generally has no effect on cystometry results.

There are limitations to our study. Results from a retrospective chart review must be interpreted cautiously. Our numbers are also too small.

The parents of these children were asked to compare the procedures regarding sedation administration and only one parent felt that the non-sedated procedure was better while two parents said that there was no difference and all the other parents stated that they preferred sedation.

\section{CONCLUSION}

The child needs to be calm and cooperating during the invasive procedure of cystometry. We did not find rectal midazolam to cause any negative effect on cystometry data in this study. Effective sedation was found with rectal administration. A lower dose was used with the rectal route without irritation or spitting. We noted that urination after cystometry occurred easily in patients with sedation. We believe that sedation with rectal midazolam is a safe, effective and convenient option during cystometry.

\section{Funding}

This research was carried out without funding.

\section{Conflict of interest}

No conflicts of interest declared.

\section{ACKNOWLEDGMENT}

We gratefully acknowledge the statistical analysis performed by Assoc Prof Erdem Karabulut.

\section{REFERENCES}

1. Phillips D, Watson AR, Collier J. Distress and radiological investigations of the urinary tract in children. Eur J Pediatr 1996;155:684-7.

2. Herd DW, McAnulty KA, Keene NA, Sommerville DE. Conscious sedation reduces distress in children undergoing voiding cystourethrography and does not interfere with the diagnosis of vesicoureteric reflux: A randomized controlled study. Am J Roentgenol 2006;187:1621-6. 
3. Akil I, Ozkol M, Yilmaz Ikizoglu O, Polat M, Tuncyurek OY, Taskin $\mathrm{O}$, et al. Premedication during micturating cystourethrogram to achieve sedation and anxiolysis. Pediatr Nephrol 2005;20:110610.

4. Thevaraja AK, Batra YK, Rakesh SV, Panda NB, Rao KL, Chhabra $\mathrm{M}$, et al. Comparison of low-dose ketamine to midazolam for sedation during pediatric urodynamic study. Pediatric Anesthesia 2013;23:415-21.

5. Malinovsky JM, Populaire C, Cozian A, Lepage JY, Lejus C, Pinaud M. Premedication with midazolam in children. Effect of intranasal, rectal and oral routes on plasma midazolam concentrations. Anaesthesia 1995;50:351-4.

6. Kogan A, Katz J, Efrat R, Eidelman LA. Premedication with midazolam in young children: A comparison of four routes of administration. Paediatric Anaesthesia 2002;12:685-9.

7. Özmert S, Sever F, Tiryaki T. Evaluation of the effects of sedation administered via three different routes on the procedure, child and parent satisfaction during cystometry. Springerplus 2016;5:1496.

8. Neveus T, von Gontard A, Hoebeke P, Hjälmås K, Bauer S, Bower $\mathrm{W}$, et al. The standardization of terminology of lower urinary tract function in children and adolescents: report from the Standardisation Committee of the International Children's Continence Society. J Urol 2006;176: 31424

9. Koff SA. Estimating bladder capacity in children. Urology 1983;21:248

10. Gray M. Traumatic urethral catheterization of children. Pediatric Nursing 1996;22:306-10.
11. Goodman TR, Kilborn T, Pearce R. Warm or cold contrast medium in the micturating cystourethrogram (MCUG): Which is the best? Clinical Radiology 2003; 58: 551-4.

12. Gerard LL, Cooper CS, Duethman KS, Gordley BM, Kleiber CM. Effectiveness of lidocaine lubricant for discomfort during pediatric urethral catheterization. Journal of Urology 2003;170:564-7.

13. Butler LD, Symons BK, Henderson SL, Shortliffe LD, Spiegel D. Hypnosis reduces distress and duration of an invasive medical procedure for children. Pediatrics 2005;115:77-85.

14. Ozkurkcugil C, Ozkan L. Effects of anesthetics on cystometric parameters in female rats. Int Urol Nephrol 2010;42:909-13.

15. Ameda K, Kakizaki H, Yamashita T, Nonomura K, Shinno Y, Kemmotsu $\mathrm{O}$, et al. Feasibility of urodynamic study (combined cystometry and electromyography of the external urethral sphincter) under general anesthesia in children. Int J Urol 1997;4:32-9.

16. Malinovsky JM, Le Normand L, Lepage JY, Malinge M, Cozian A, Pinaud $M$, et al. The urodynamic effects of intravenous opioids and ketoprofen in humans. Anesth Analg 1998;87:456-61.

17. Ceran C, Pampal A, Goktaş O, Pampal HK, Olmez E, et al. Commonly used intravenous anesthetics decrease bladder contractility: An in vitro study of the effects of propofol, ketamine and midazolam on the rat bladder. Indian J Urol 2010;26:364-8.

18. Sweeney H, Rzepski B, Hochman H, Kim C, Lerer T, Ferrer F, et al. Identifying characteristics of children requiring sedation for urodynamics. Urologic Nursing 2008;28:269-72.

19. Bozkurt P, Kilic N, Kaya G, Yeker Y, Elicevik M, Söylet Y. The effects of intranasal midazolam on urodynamic studies in children. $\mathrm{Br} J$ Urol 1996;78:282-6. 